\title{
IMPROVING STUDENTS' READING COMPREHENSION THROUGH THE USE OF NUMBERED HEAD TOGETHER (NHT) TECHNIQUE
}

\author{
Yustina Selong \\ STKIP Pamane Talino \\ yustinaselong7@gmail.com
}

\begin{abstract}
Together (NHT) was used as the technique to improve students' reading comprehension which was conducted in two cycles. The subject of this research were the tenth grade students of social 3 class in SMA Negeri 2 Sungai Kakap in the academic year of 2017/2018. The class consisted of 35 students. The data collection used observation and measurement technique. The results showed that Numbered Head Together (NHT) technique could improve students' ability in reading comprehension. Moreover, it could influence the students' attention, and also motivated them in learning activities as the result of the groups' discussion. Through the use of Numbered Head Together (NHT) technique, the students were able to participate in teaching learning process. They became serious in listening to the teacher's explanations and worked cooperatively with their friends in each group. They were also more active, enthusiastic, and more confident in following class activities which resulted on the better atmosphere of the classroom that was more enjoyable and alive.
\end{abstract}

Keywords: Reading Comprehension, Numbered Head Together and Classroom Action Research

\section{INTRODUCTION}

The Reading as one of skills, it has an important role in teaching and learning English. Patel and Jain (2008: 113-114), reading is the most important activity in any language class. Reading is an active process which consists of recognition and comprehension skill. "comprehension may be regarded as relating aspects of the world around us including what we read to the knowledge, intentions, and expectations we already have in our head" (smith. F, 2004:13). It means that reading comprehension is the process or important activity to recognize and to comprehend what we read.

Moreover, Moreillon (2007:10) explains that reading is an active process of how the reader making meaning from the print and visual information that requires a great deal of practice and skill. Means that, reading is the process of getting information, to communicate and to create meaning of the written text. It is one of the way to improve the knowledge or ability because the more we read the more we understand many aspects of the world. Miqawati and Sulistyo (2014:126) state that "Reading comprehension can be improved by employing certain strategies in the form of study skills". So, any kind of skills in teaching and learning process can be helped by the implementation of techniques.

In teaching and learning process, the teacher had important role and must know the students' characteristic because each of students in the class had different characters. As in the tenth grade students of social 3 class in SMA Negeri 2 Sungai Kakap, the researcher found some problems faced by the students in learning English reading comprehension. 
When the teacher let the students read the text, most of them could read. Nevertheless, when the teacher asked them to tell about the passage of the text, they were confused and some of them said that they did not understand what the text about. Beside that, some students could categorized as active student, but some of them could categorized as passive students.

For the passive students, sometimes they did not want to ask questions to the teacher even if they didn't understand the materials. As the result, they forgot to the materials as soon as possible and they could not improve their knowledge. The students also got difficulties to answer the questions related to the text and difficult to find out the main idea of the text. Even, a teacher had to translate the text to make them understand the passage clearly. Therefore, based on the problem which has been stated, the researcher implemented Numbered Head Together (NHT) as an enjoyable technique to improve students' reading comprehension.

According to Kagan in Novitasari (2013:3) numbered head together is kind of cooperative learning as it includes teams and individual accountability that lead to cooperative interaction among students. It means that with NHT technique the students are interacting each other and they work together in the team or group. When they work in a group, they get opportunities in the learning activities and thinking process actively.

Risnaldi (2016:117) also mention some positive impacts to the students through the implementation of Numbered Heads Together technique in learning reading, such as: learning enthusiasm can be higher, being brave on giving opinions, easier in accomplishing the difficult questions, more interested in group working, being more confident, easier to compromise with friends, not easily being bored in learning, can be closer with friends in working, more accustomed in group working, more interested to share knowledge within the group. "It also can increase the students' achievement (Nurdiana, 2016:39). Therefore, it can be concluded that Numbered Head Together (NHT) not only give many advantages but also give some positive impacts to the students in learning process.

High (1993) in Gustadevi, Ngadiso \& Asib (2012:194) emphasizes that "NHT is effective because all students in group are held equally responsible and have motivation to support one's another learning". It enable the students to be more active, confidence and enthusiastic in explaining the answer especially for poor students or lower students who usually ashamed in class. Through NHT technique the students can express their thinking without being afraid and they work cooperatively to solve the problems. Moreover, Trianto (2009:28) in Regina \& Mulyadi (2016:43) describes how Numbered Head Together (NHT) technique applied and used by teacher in teaching reading. The phases of teaching procedure can be seen in table as below: 
The Phases in Numbered Head Together (NHT) Technique

\begin{tabular}{|c|c|}
\hline Phases & Teacher Activities \\
\hline $\begin{array}{l}\text { First Phase } \\
\text { Numbering }\end{array}$ & $\begin{array}{l}\text { The teacher divides students into a group, every group } \\
\text { consist about three until six students. Then, each member } \\
\text { of them is given number from one to six. }\end{array}$ \\
\hline $\begin{array}{l}\text { Second Phase: Asking } \\
\text { the Question }\end{array}$ & $\begin{array}{l}\text { The teacher asks some questions to students. the question } \\
\text { can be a specific by using the interrogative sentence or } \\
\text { the sentence it based on the purpose of teaching and } \\
\text { learning process }\end{array}$ \\
\hline $\begin{array}{l}\text { Third Phase: Thinking } \\
\text { Together }\end{array}$ & $\begin{array}{l}\text { This is the discussion time. Students are given the same } \\
\text { time to discuss the answer of the questions in their group. } \\
\text { The time given must be short. It means, the time is } \\
\text { limited in order to access all groups get an opportunity in } \\
\text { doing discussion. }\end{array}$ \\
\hline $\begin{array}{l}\text { Fourth } \\
\text { Answering }\end{array}$ & $\begin{array}{l}\text { After giving all students time to discuss about the topic, } \\
\text { teacher calls a student (ask randomly, but try to look at } \\
\text { the students who has low proficiency. Then, the students } \\
\text { who get a turn to answer must rise their hand and answer } \\
\text { the question bravely to the class. }\end{array}$ \\
\hline
\end{tabular}

Based on the table above, it can be concluded that in the first step of teaching and learning process through the use of NHT technique, the students were divided by the teacher into a group. Then, students in each group were given a number by the teacher as their identity. After that, the teacher gave some questions and students were discussed together to answer the questions. The last phase, students were pointed randomly by the teacher to answer the questions bravely represented their group answer.

\section{METHOD}

The method used in this research was Classroom Action Research. "Classroom Action Research is a method of finding out what works best in own classroom so that teacher can improve student learning" (Khasinah, 2013:113). Murcia (2001:490) also said that "It simply tries to investigate what happens inside the classroom when learners and teachers come together." Means that when the researcher doing the research, the researcher wants to know what 
problems happened in teaching learning process in the class, then figure out how to overcome the problems. It is very important because without any method in teaching and learning process the objective of learning can't achieved by the students.

According to Coats (2005:5), in action research the process is planning, acting, observing and reflecting. Kurt Lewin, McNiff and Whitehead, (2002:40) stated that action research: planning, acting, observing, reflecting. Then, Kemmis and Mc Taggart (1992) in Burns (2010.p.9) also mention those four phases. Therefore, each cycle of this research has been done with a process called planning, acting, observing, and reflecting.

The subject of this research was the tenth grade students of SMA Negeri 2 Sungai Kakap in academic year 2017/2018. This school was located at Jl. Daeng Hasyim Ds. Jeruju Besar, Sungai Kakap, Kubu Raya regency, West Kalimantan. There were 4 classes consists of 1 science class and 3 social classes (social 1, 2 and 3). Nevertheless, in implementing the Numbered Head Together technique in this research, the researcher focused on the tenth grade students of social 3 class.

In conducing this research, there were 2 cycles and in each cycle there were two meetings. The first meeting used for the treatment and the second meeting used for reading comprehension test. From each cycle then the researcher described the process of class activities during the treatment. Furthermore, the technique of data collection in this research used observation and measurement test.

The tool of data collection were observation checklist table, field note, and reading comprehension test. In observation part, the researcher did observation in classroom, made conclusion and description about what happened during class activities in the teaching and learning process.

Observation checklist table is the table consists of some statements about class activities in teaching and learning process. Ary, Jacobs, Sorensen and Razavieh (2010:217) said that, "The simplest device used is a checklist, which presents a list of the behaviors that are to be observed. The observer then checks whether each behavior is present or absent." It is the way how to monitor and knowing the students' behavior in learning process. In this phase, it was the time that "The observer records the things he or she observes as categories of events, for example behaviors, or types of interaction" (Burns, 2010:62). So, it is not only about the teacher and students' performance in the class, but also about teacher-students interaction and studentsstudents interaction. 
To get the complete data, the researcher filled the field note. According to Ary, Jacobs, Sorensen and Razavieh (2010:526), field notes were the most common data collection strategy used in action research to provide a record of what is going on during an observation. Means that the researcher noted lots of information related with the teaching and learning in every cycle process. She noted the important points during class activities to support the data that were not included in observation checklist table.

Finally, for the measurement test in this research used written test about reading comprehension kind of narrative text. Narrative text is the text that usually only in the form of the author's imagination or a real incident that was captured by the author or even a combination of both (Mislaini, 2015:3). The form of the test was essay. Ary, Jacobs, Sorensen and Razavieh (2010:201) explain that, "A test is a set of stimuli presented to an individual in order to elicit responses on the basis of which a numerical score can be assigned." Therefore, the aim of this test is to assess the students' reading comprehension ability after given the implementation of Numbered Head Together technique.

\section{FINDING AND DISCUSSION}

\section{a. Finding}

In this research, the researcher explained the steps of the findings in cycle 1 and cycle 2 as qualitative data. Besides, the researcher also presented the students' test results that had been calculated as quantitative data findings to support the qualitative data of this research.

Based on the qualitative data findings result of cycle 1 and cycle 2, the researcher found the improvement of students' reading comprehension during the learning process. Most of students more enthusiastic to follow the lesson through the use of Numbered Head Together technique. When the researcher gave explanation about the steps of the technique, all students paid attention and listened well. Beside that, all of the students could work in their group and participated actively during class activities. They more active and serious in discussing the topic so that they could comprehend the text well. It showed that when the researcher asked them some questions related to the story orally, most of them could give correct information as evidence clearly enough.

The passive students also enjoyed the class activities even they could show their confidence in both asking and answering questions. Even, the passive students also be brave to ask the teacher when they got difficulties in comprehending the meaning of words in reading text. In addition, the interaction among the researcher with the students became more communicative and the atmosphere of classroom also more cheerful and not boring to the students. After describing the observation result and the test result, the researcher calculated the students' achievement through written test to support 
the result of qualitative data. The result showed that there were some improvements achieved after doing the action through the use of Numbered Head Together Technique.

Based on the result of reading comprehension test, the researcher found the students' individual score. The students' individual score in cycle 1 found that the lowest score was 50 categorized as poor and the highest score was 90 categorized as very good. It means that there was only 1 student or $3 \%$ student was categorized as very good, 10 students or $28.5 \%$ students were categorized as good, 10 students or $28.5 \%$ students were categorized as fair, 14 students or $40 \%$ students were categorized as poor, and there's nobody who categorized as excellent and very poor. Nevertheless, the implementation of the action in cycle 1 showed that there were some students still got confused to make inferences because each of them had their own opinion in giving ideas to answer the questions given by the researcher. Therefore, to overcome the problem in cycle 1, the researcher continued to implement the action of NHT technique for cycle 2.

In cycle 2, the students' difficulties to make inferences of the reading text were decreased. Besides that, the researcher found the improvement of the students' individual score. The students' individual score in cycle 2 was better than the students' individual score in cycle 1 . The lowest score in cycle 2 was 60 that categorized as poor score, while the highest score was 100 that categorized as excellent score. In another words, there were 5 students or $14 \%$ students were categorized as excellent, 10 students or $29 \%$ students were categorized as very good, 11 students or $31 \%$ students were categorized as good, 7 students or $20 \%$ students were categorized as fair, 2 students or $6 \%$ students were categorized as poor, and nobody who categorized as very poor.

From the analysis result of cycle 1 and cycle 2 which had stated above, the students' problem in reading comprehension could be improved and solved. It indicated that the students' reading comprehension could improve through the use of Numbered Head Together technique.

\section{b. Discussion}

During the implementation of NHT technique, the researcher found that all students were able to enjoy the learning process and class activities without getting bored. The class atmosphere and the students' attitude also look different before and when implementation of the action. The result of observation before the treatment showed that most of students got difficulties to comprehend the reading text because the teacher explained the material without any technique. In other words, the teacher just delivered the material based on instructions that have been involved in reading text. Therefore, the students could not focus in learning process. Sometimes, some of them feel sleepy, getting bored, lack of confidence and they become passive. But, after the students given the treatment by the researcher, they showed the great improvement in learning process and class situation also become alive. 
In the first meeting of cycle 1 , there were some students who still getting confused when the researcher explained the rules of learning using the NHT technique. But it's normal because the students have never been taught by the previous teacher with that technique. So to achieve a target in the process of learning, the researcher explain the rules clearly and provide an example to the students. At the time, most of students paid more attention to the researcher's explanation and they could follow the lesson well. Nevertheless, it's still not enough satisfying for the researcher because there were some students who like to make joke when they were having a discussion in a group. It could make the other students less focused because some of them laughed with a laud voice. So that the researcher decided to continue the second action for Cycle 2.

In implementing the action in cycle 2, the students were enthusiastic in learning process, become more confident to ask or answer the questions from the researcher according to the reading text, and they were able to participate in group discussion actively. While discussion, the students in each group shared their idea to their friends and then they wrote the information that they have got from reading text. So that, the students were able to comprehend the reading text literally and then could draw conclusions from what they have read.

The result of learning activities in Cycle 2 showed that the students' reading comprehension was improved. The students were able to discuss in each group actively without getting bored, they answered the questions seriously and more active in following the lesson. Then, the result of the students' reading comprehension was taken from the tests of cycle 1 and cycle 2 .

Teaching reading through the use of Numbered Head Together (NHT) technique, the students were able to comprehend the text easily and they could help each other in solving the problem. Besides that, they were able to participate actively and work cooperatively during teaching and learning process. Therefore, the class activities could run well and the situation of the classroom also became more alive and enjoyable. It was because there were interaction among the students and also with the teacher.

Based on the results of the research that had been conducted by the researcher in two cycles, from cycle 1 to cycle 2 showed an improvement of students' reading comprehension. So, the researcher took decision that the research considered successful and stopped after cycle 2 because the target of teaching learning process was achieved with expectations. In short, NHT technique could help the students in improving their reading comprehension enjoyable.

\section{CONCLUSION}

After conducting the research in the tenth grade students of social 3 class in SMA Negeri 2 Sungai Kakap through the use of Numbered Head Together (NHT) technique, the results showed that it could improve the students' participation in a reading for comprehension class. Besides, students were able to 
comprehend the text literally and make inferences or draw conclusion of the reading text that have been learnt in classroom.

Furthermore, the use of Number Head Together (NHT) technique could change the students' attitude or behavior. It also gave positive influence to the students' attention.

During the process of teaching learning, students more enthusiastic, more confident to answer the questions given by the researcher and they were able to participate actively in groups' discussion so that the atmosphere of classroom became more alive and communicative. The students also could paid more attention and serious in following class activities without getting bored or sleepy.

\section{REFERENCES}

Ary, D., Jacobs, L. C., Sorensen, C., \& Razavieh, A. (2010). Introduction to Research in Education. Canada: Nelson Education, Ltd.

Burns, A. (2010). Doing Action Research in English Language Teaching: A Guide for Practitioners. New York and London: Routledge.

Celce Murcia, M. (2001). Teaching English as a Second or Foreign Language. USA: Heinle \& Heinle.

Coats, M. (2005). Action Research A Guide for Associate Lecturers. United Kingdom: The Open University.

Gustadevi, A. S., Ngadiso, \& Asib, A. (2012). Improving Students' Reading Skill Through Numbered Head Together Technique. Surakarta: Sebelas Maret University.

Khasinah, S. (2013). Classroom Action Research. Jurnal Pionir. Vol.1, No.1, 107-114.

Maman, M. (2016). The Implementation of Cooperative Learning Model 'Number Heads Together (NHT)' in Improving the Students' Ability in

Reading Comprehension. International Journal of Evaluation and Research in Education (IJERE), 174180.

Mardianti, V., E, J., Ohoiwutun, \& Wahyudin. (2014). Improving Students' Reading Comprehension Through Schema Activation Strategy. E-Journal of English Language Teaching Society (ELTS) Vol. 2 No. 1, 1-16.

McNiff, J., \& Whitehead, J. (2002). Action Research: Principles and Practice. RoutledgeFalmer: London $\&$ New York.

Miqawati, A. H., \& Sulistyo, G. H. (2014). The PQRST Strategy, Reading Comprehension, and Learning Styles. Indonesian Journal of Applied Linguistics, Vol. 4 No. 1, 123-139.

Mislaini. (2015). Improving Students' Reading Comprehension of Narrative Text by Using Fable at the Grade X SMAN 1 Bonai Darussalam. 1-8.

Moreillon, J. (2007). Collaborative Strategies for Teaching Reading Comprehension Maximizing Your Impact. Chicago: American Library Association. 
Novitasari, R., \& Abdullah, S. (2013). The Implementation of "Numbered Heads Together" in Teaching Reading Narrative Text to the Tenth Graders. E-Jurnal Unesa. Volume 01 Nomor 01, 1-9.

Nurdiana. (2016). Using Numbered Head Together Technique on Students' Reading Comprehension. IJIELT Indonesian Journal of Integrated English Language Teaching Vol. 2 No. 1, 37-47.

Patel, M., \& Jain. (2008). English Language Teaching: Method, Tools \& Techniques. Sunrise Publishers $\&$ Distributors.

Rayanto, Y. H. (2017). Using Numbered Head Together to Improve The Student's Reading Comprehension in Narrative Text. IOSR Journal of Research \& Method in Education (IOSRJRME), 107-114.

Regina, R., \& Mulyadi, S. (2016). The Use of Number Heads Together (NHT) in Teaching Speaking for Junior High School. Getsempena English Education Journal Vol.2, No.1, 1-17.

Risnaldi, F. (2016). Numbered Head Together Technique on Improving Students' Reading Comprehension. Research in English and Education (READ), 114-120.

Smith, F. (2004). Understanding Reading: A Psycholinguistic Analysis of Reading and Learning to Read. London: Lawrence Erlbaum Associates.

Swastyastu, L. T. (2014). Improving Reading Comprehension of the Tenth Grade Students by Using Numbered Heads Together. Denpasar: Mahasaraswati Denpasar University. 